\title{
Effect of an Arctium lappa (Burdock) Extract on the Labeling of Blood Constituents with Technetium-99m and on the Morphology of the Red Blood Cells
}

\author{
Rosane de Figueiredo Neves ${ }^{1,2} *$, Silvana Ramos Farias Moreno ${ }^{2,3}$, Bernardo Machado \\ Rebello $^{1,2}$, Luiz Querino de Araújo Caldas $^{3}$, Adenilson de Souza da Fonseca ${ }^{2}$, Mario \\ Bernardo-Filho $^{1,2,4}$ and Aldo da Cunha Medeiros ${ }^{1}$ \\ ${ }^{I}$ Programa de Pós-Graduação em Ciências da Saúde; Universidade Federal do Rio Grande do Norte; Av. Gal. \\ Gustavo Cordeiro de Farias, s/n; 59010180; nevesrosane@yahoo.com.br; Natal - RN - Brasil. ${ }^{2}$ Universidade do \\ Estado do Rio de Janeiro; Instituto de Biologia Roberto Alcântara Gomes; Departamento de Biofísica e Biometria; \\ Av. 28 de Setembro, 87; 20551030; Rio de Janeiro - RJ - Brasil. ${ }^{3}$ Universidade Federal Fluminense; Programa de \\ Pós-Graduação em Ciências Médicas; Rua Marquês de Paraná, 303; 24030210; Niterói - RJ - Brasil. ${ }^{4}$ Instituto \\ Nacional do Câncer; Coordenadoria de Pesquisa; Praça da Cruz Vermelha, 23; 20230130; Rio de Janeiro - RJ - \\ Brasil
}

\begin{abstract}
Arctium lappa (burdock) has been used to treat inflammatory processes. Blood constituents labeled with technetium-99m $\left({ }^{99 m} \mathrm{Tc}\right)$ have been utilized in nuclear medicine. It was evaluated the influence of a burdock extract on the labeling of blood constituents with ${ }^{99 m}$ Tc and on the morphometry of red blood cells. Blood samples from Wistar rats were incubated with burdock extract and the radiolabeling procedure was carried out. Plasma and blood cells, soluble and insoluble fractions of plasma and blood cells were separated. The radioactivity in each fraction was counted and the percentages of radioactivity (\%ATI) were determined. Morphology and morphometric (perimeter/area ratio) measurements of red blood cells $(R B C)$ were performed. The incubation with burdock extract significantly $(p<0.05)$ altered the \%ATI on the blood compartments and the perimeter/area ratio of RBC, as well as, induced modifications on the shape of RBC. Alterations on membrane could justify the decrease of labeling of blood cells with ${ }^{99 m}$ Tc obtained in this study.
\end{abstract}

Key words: Arctium lappa, technetium-99m, blood constituents, morphometry

\section{INTRODUCTION}

The use of medicinal plants or natural products has increased in the world (Rotblat and Ziment, 2002). Arctium lappa (burdock) has been cultivated as a vegetable for a long time in Taiwan and Japan (Morita et al., 1993). Lieber et al. (1994) have reported that this natural product has been used as a very popular health drink in Taiwan to treat hypertension, gout, arteriosclerosis, hepatitis and other inflammatory disorders. Moreover, SongChow et al. (2002) have described that the hepatoprotective mechanism associated to burdock treatment could be attributed, at least in part, to its antioxidative activity, what decreases the oxidative stress of hepatocytes, or to other unknown protective mechanism.

\footnotetext{
${ }^{*}$ Author for correspondence
} 
An investigation has demonstrated that burdock presents an inhibitory effect on the binding of platelet activating factor to rabbit platelets and this factor is resistant to heat and proteolysis enzymes (Iwakami et al., 1992). Lin et al. (1996) reported that burdock has anti-inflammatory and free radical-scavenging activities. Arctigenin, a chemical compound present in burdock, appears to have antimutagenic effect and to inhibit the in vitro tumor growth (Lin et al., 1996).

In nuclear medicine, red blood cells (RBC) are labeled with technetium-99m $\left({ }^{99 \mathrm{~m}} \mathrm{Tc}\right)$ and used to detect clinical disorders (Saha, 2004; BernardoFilho et al., 2005). The labeling of blood constituents with ${ }^{99 \mathrm{~m}} \mathrm{Tc}$ is also used as an experimental assay to evaluate in vitro (Moreno et al., 2004; Abreu et al., 2006) and in vivo (Fonseca et al., 2007) interactions between drugs and radiopharmaceuticals (radiobiocomplexes). This labeling technique involves the intracellular reaction between reduced ${ }^{99 \mathrm{~m}} \mathrm{Tc}$ and hemoglobin (Owunwanne et al., 1995). When the blood is labeled with ${ }^{99 \mathrm{~m}} \mathrm{Tc}$, the radioactivity is mainly found on cellular compartment and, but it is also fixed on plasma proteins (Bernardo-Filho et al., 1990). Plasma proteins labeled with ${ }^{99 \mathrm{~m}} \mathrm{Tc}$ are used for evaluation of lung perfusion (Hunt et al., 2006), hepatic tumors and portal hemodynamic changes (Schneider et al., 2003).

Authors have reported that extracts of some medicinal plants are capable to alter the labeling of blood constituents with ${ }^{99 \mathrm{~m}} \mathrm{Tc}$ (Oliveira et al., 2003; Moreno et al., 2004; Abreu et al., 2006), while other extracts are not capable to interfere in this labeling (Fernandes et al., 2005).

Morphometric analysis has been used as a tool for research in several studies, such as: (i) to verify changes in optic disc structure and thickness of retinal nerve fibre layer in chronic ocular hypertensive monkeys (Shimazawa et al., 2006), (ii) to study the relationship between infarctrelated artery stenosis and capillary density (Prech et al., 2005) and (iii) to evaluate the effects of sex hormones on normal mammary gland of rats (Pompei et al., 2005). Engström and Löfvenberg (1998) have described that after treatment with hydroxyurea, the membrane area of RBC has an increase of $24 \%$ and the cell volume has an increase of 39\%. Berezina et al. (2004) showed that alterations on shape of RBC appear within the first hours after trauma and persist for at least 7 to 10 days. These changes are more severe in patients with secondary septic complications. Panis and
Souza (2005) have studied the volume of RBC exposed to osmotic stress and have observed that the hematocrit ratio, mean corpuscular volume, optical density and the mean cellular hemoglobin yield were significantly altered.

The morphometric analysis of RBC treated with plant extracts has also been utilized to evaluate possible alterations of area, shape and volume of these cellular structures (Moreno et al., 2004; Oliveira et al., 2005).

The aim of this work was to evaluate the effect of a burdock extract on the labeling of blood constituents with ${ }^{99 \mathrm{~m}} \mathrm{Tc}$ and its action on the morphology of red blood cells.

\section{MATERIALS AND METHODS}

The burdock extract was prepared with $2 \mathrm{~g}$ of leaf, stem and flowers of Arctium lappa (Estrella da Terra Produtos Naturais LTDA, Brazil, lot number 002, expiration date August 2005) in $100 \mathrm{~mL}$ of $0.9 \% \mathrm{NaCl}$ solution at room temperature. It was triturated with a domestic electric extractor. This mixture was filtered (Schleicher and Schulle filter paper) and the filtered solution was considered to be $20 \mathrm{mg} / \mathrm{mL}$. All the experiments were performed up to June 2005.

Absorption spectrum of burdock extract (400$700 \mathrm{~nm}$, intervals of 20nm) obtained by spectrophotometer (Analyser 800M, Analyser Comércio e Indústria LTDA, São Paulo, Brazil) was used as reproductively marker of this extract (Fig. 1).

The protocols of the experiments were approved by the Ethical Committee of the Instituto de Biologia Roberto Alcantara Gomes, Universidade do Estado do Rio de Janeiro (protocol number CEA/141/2006).

Samples $(0.5 \mathrm{~mL})$ of heparinized blood from adult male Wistar rats (3-4 months, 262 $\pm 12 \mathrm{~g}$ ) were incubated with $100 \mu \mathrm{L}$ of different concentrations of burdock extract $(1.25,2.5,5.0,10$ and $20 \mathrm{mg} / \mathrm{mL}$ ) for 1 hour at room temperature. Blood samples also were incubated with saline solution $(0.9 \% \mathrm{NaCl})$ as controls. Afterwards, $0.5 \mathrm{~mL}$ of a freshly prepared stannous chloride solution $(1.2 \mu \mathrm{g} / \mathrm{mL}$, Sigma, USA) was added and the incubation continued for another 1 hour. After this period of time, ${ }^{99 \mathrm{~m}} \mathrm{Tc}(100 \mu \mathrm{L}, 3.7 \mathrm{MBq} / \mathrm{mL})$, as sodium pertechnetate, recently milked from a ${ }^{99} \mathrm{Mo} /{ }^{99 \mathrm{~m}} \mathrm{Tc}$ generator (Instituto de Pesquisas 
Energéticas e Nucleares, Comissão Nacional de Energia Nuclear, Brazil), was added and the incubation continued for $10 \mathrm{~min}$. The samples were centrifuged (1500 rpm, $5 \mathrm{~min}$ ) and aliquots of plasma $(\mathrm{P})$ and blood cells $(\mathrm{BC})$ were separated. Samples $(20 \mu \mathrm{L})$ of $\mathrm{P}$ and $\mathrm{BC}$ were also precipitated with $1 \mathrm{~mL}$ of trichloroacetic acid (5\%) and the soluble (SF) and insoluble fractions (IF) were separated. The radioactivity in $\mathrm{P}, \mathrm{BC}$, IF-P, SF-P, IF-BC and SF-BC was determined in a well counter (Automatic Gamma Counter, C5002, and Packard, USA). After that, the percentage of radioactivity (\%ATI) was calculated, as previously reported (Bernardo-Filho et al., 1983).

A morphometric study of the samples was also performed. Blood smears were prepared in glass slides (5 slides for each sample) and the MayGrünwald-Giemsa (MGG) method was performed (Barcia, 2007). The smears were evaluated under optical microscope of clear field (Eclipse E $\left.400^{\mathrm{TM}}\right)$, in the immersion objective $(100 \mathrm{x})$, with photographer ocular. The quantification of the data was realized by Software image pro plus (media
Cybernetics) to measure automatically the area and perimeter of the RBC.

Statistical analysis (Kruskal-Wallis com pós-teste Dunns, $\mathrm{p}<0.05$ ) was used to compare the experimental data, based on the morphometry evaluation.

\section{RESULTS}

The absorption spectrum of the burdock extract used in the experiments is showed in Fig. 1. It presented the highest measure of the optical density (0.754) at $500 \mathrm{~nm}$.

Table 1 presents the effects of a burdock extract on the radioactivity distribution between cellular and plasma compartments. These data indicate that burdock extract could induce a significant alteration $\quad(\mathrm{p}<0.05)$ of ${ }^{99 \mathrm{~m}} \mathrm{Tc}$ in these compartments.

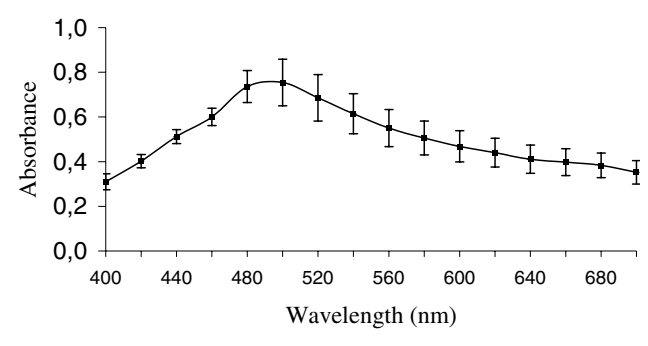

Figure 1 - The absorption spectrum of a burdock extract.

Table 1 - Effect of burdock extract on the radioactivity distribution on the cells and plasma compartments labeled with ${ }^{99 \mathrm{~m}} \mathrm{Tc}$.

\begin{tabular}{|c|c|c|}
\hline Burdock (mg/mL) & $\mathbf{P}$ & BC \\
\hline 0.00 (control) & $3.76 \pm 1.11$ & $96.24 \pm 1.11$ \\
\hline 1.25 & $15.67 \pm 0.12$ & $84.33 \pm 0.12$ \\
\hline 2.5 & $16.49 \pm 0.38$ & $83.51 \pm 0.38$ \\
\hline 5.0 & $15.69 \pm 1.43$ & $84.31 \pm 1.43$ \\
\hline 10 & $15.39 \pm 1.47$ & $84.61 \pm 1.47$ \\
\hline 20 & $22.89 \pm 1.35$ & $77.11 \pm 1.35$ \\
\hline
\end{tabular}

Blood samples were incubated with burdock extract and radiolabeling procedure was performed. Plasma and blood cells were isolated, radioactivity was counted and the percentage of incorporated radioactivity (\%ATI) was calculated. $(*)$ p $<0.05$ when compared with control. 
Table 2 presents the effect of burdock extract on the fixation of ${ }^{99 \mathrm{~m}} \mathrm{Tc}$ on insoluble and soluble fractions plasma proteins. These data indicate that the burdock extract was not capable to interfere on the fixation of the radioactivity on the insoluble and soluble fractions of plasma.

No alteration on fixation of radioactivity on proteins of blood cells from blood samples incubated with burdock extract (Table 3) was found.

Table 4 presents the perimeter/area ratio of red blood cells from blood samples incubated with burdock extract. The results indicate that the perimeter/area ratio was significantly $(p<0.05)$ altered in the samples incubated with burdock extract at the highest concentrations used (10 and $20 \mathrm{mg} / \mathrm{mL}$ ).

The qualitative evaluation of the shape of the red blood cells (incubated with $0.9 \% \mathrm{NaCl}$ and incubated with burdock at $20 \mathrm{mg} / \mathrm{mL}$ ) under optical microscopy is shown in the Figs. 1 and 2.

Alterations on the morphology of the RBC incubated with burdock extract at the higher concentration were found (Fig. 2) when compared with control (Fig. 1).

Table 2 - Effect of burdock extract on the fixation of radioactivity on the insoluble and soluble fractions of plasma.

\begin{tabular}{lll}
\hline Burdock $(\mathbf{m g} / \mathbf{m L})$ & \%F-Plasma & IF ATI \\
\hline 0.00 (control) & $72.06 \pm 1.30$ & $27.94 \pm 1.30$ \\
1.25 & $72.13 \pm 2.10$ & $27.87 \pm 2.10$ \\
2.5 & $70.66 \pm 2.06$ & $29.34 \pm 2.06$ \\
5.0 & $73.84 \pm 1.40$ & $26.16 \pm 1.40$ \\
10 & $70.00 \pm 0.32$ & $30.00 \pm 0.32$ \\
20 & $70.79 \pm 0.48$ & $29.21 \pm 0.48$ \\
\hline
\end{tabular}

Blood samples were incubated with burdock extract and radiolabeling procedure was performed. Plasma and blood cells were separated, insoluble (IF) and soluble (SF) fractions of plasma were isolated by precipitation in trichloroacetic acid. The radioactivity was counted and the percentage of incorporated radioactivity (\%ATI) was calculated.

Table 3 - Effect of burdock extract on the fixation of radioactivity on the insoluble and soluble fractions of the blood cells.

\begin{tabular}{|c|c|c|}
\hline Burdock (mg/mL) & SF-Blood cells & IF-Blood cells \\
\hline 0.00 (control) & $87.56 \pm 1.71$ & $12.44 \pm 1.71$ \\
\hline 1.25 & $89.12 \pm 0.31$ & $10.88 \pm 0.31$ \\
\hline 2.5 & $85.93 \pm 1.92$ & $14.07 \pm 1.92$ \\
\hline 5.0 & $83.86 \pm 2.45$ & $16.44 \pm 2.45$ \\
\hline 10 & $88.79 \pm 2.20$ & $11.21 \pm 2.20$ \\
\hline 20 & $86.96 \pm 1.27$ & $13.04 \pm 1.27$ \\
\hline
\end{tabular}

Blood samples from Wistar rats were incubated with burdock extract and radiolabeling procedure was performed. Plasma and blood cells were separated, insoluble (IF) and soluble (SF) fractions of blood cells were isolated by precipitation in trichloroacetic acid. The radioactivity was counted and the percentage of incorporated radioactivity (\%ATI) was calculated.

Table 4 - Effect of burdock extract on perimeter/area ratio of red blood cells.

\begin{tabular}{lc}
\hline Burdock $(\mathbf{m g} / \mathbf{m L})$ & Perimeter/area $(\mathbf{1} / \boldsymbol{\mu m})$ \\
\hline $0.00($ control $)$ & $0.42 \pm 0.011$ \\
1.25 & $0.44 \pm 0.016$ \\
2.5 & $0.45 \pm 0.012$ \\
5.0 & $0.44 \pm 0.008$ \\
$10(*)$ & $0.66 \pm 0.043$ \\
$20(*)$ & $0.71 \pm 0.011$ \\
\hline
\end{tabular}

Blood samples were incubated with burdock extract for 60 minutes. After that, blood smears were prepared, dried and stained with a total of five fields per each slide and five slides to each extract concentration. Images were captures and the software Image pro plus, media Cibernetics, USA) was used to determinate the perimeter/area ratio. $(*) \mathrm{p}<0.05$ when compared with control. 


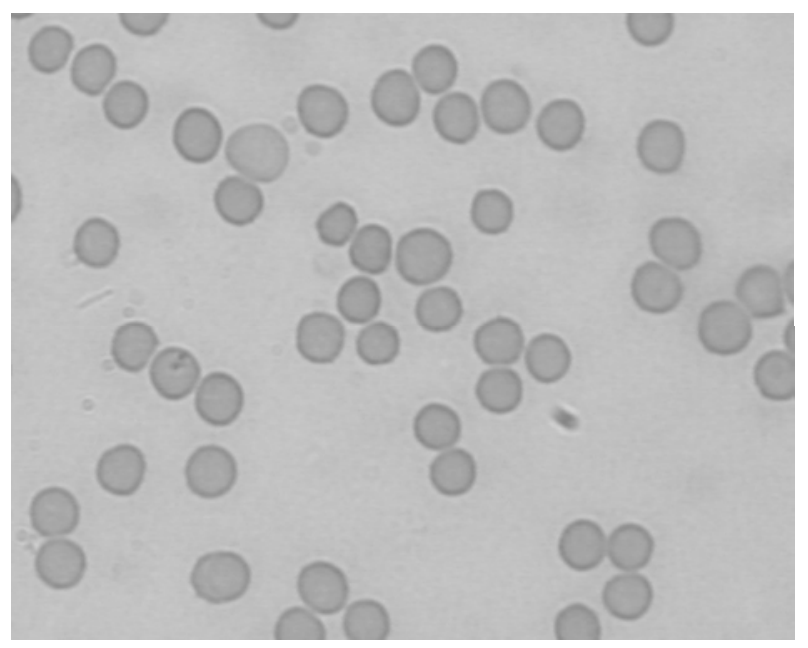

Figure 2 - Photomicrography of blood smear from blood incubated with $0.9 \% \mathrm{NaCl}$ (control). Blood samples from Wistar rats were incubated with saline $(0.9 \% \mathrm{NaCl})$ for 60 minutes. After that, blood smears were prepared, dried and stained by May-GrünwaldGiemsa method. The slides were analyzed by optical microscopy (x1000)

\section{DISCUSSION}

The labeling of blood constituents with ${ }^{99 \mathrm{~m}} \mathrm{Tc}$ has been used as an experimental model to assess some important biological properties of natural products extracts. Extracts of different medicinal plants, as Ginkgo biloba (Moreno et al., 2002; Moreno et al., 2004), Paullinia cupana (Oliveira et al., 2003) and Hypericum perforatum (Santos-
Filho and Bernardo-Filho, 2005) could alter the labeling of blood constituents with ${ }^{99 \mathrm{~m}} \mathrm{Tc}$. However, extracts of pfaffia $s p$. (Fernandes et al., 2005) were not capable to interfere in this labeling. These findings are worthwhile to justify this model using the labeling of blood constituents with ${ }^{99 \mathrm{~m}} \mathrm{Tc}$, as an important scientific tool to study properties of physical and chemical agents.

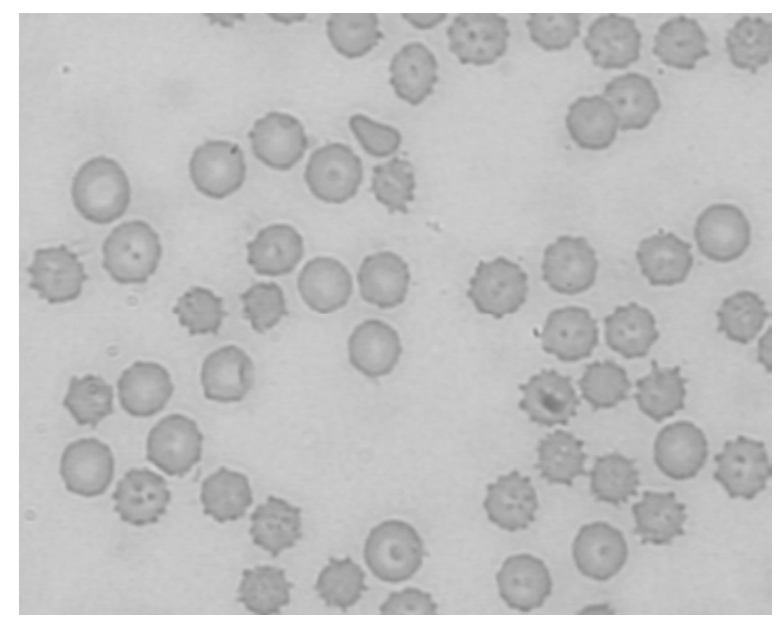

Figure 3 - Photomicrography of blood smear from blood incubated with burdock extract. Blood samples from Wistar rats were incubated with burdock extract $(20 \mathrm{mg} / \mathrm{mL})$ for 60 minutes. After that, blood smears were prepared, dried and stained by May-GrünwaldGiemsa method. The slides were analyzed by optical microscopy (x1000) 
Chemical compounds in burdock extract have been demonstrated to interfere with platelet function (Iwakami et al., 1992). The findings about the decrease of the radioactivity in blood cell compartment (Table 1) could be explained due to the action of the burdock extract on the membrane of the RBC.

As it is indicated in the Table 2, the burdock extract was not capable to interfere on the fixation of the radioactivity on the cellular and plasma proteins (IF-Plasma and IF-Blood cells, respectively). The binding of compounds present in burdock extract seems not interfere with the fixation of ${ }^{99 \mathrm{~m}} \mathrm{Tc}$ on these proteins.

Some authors have described that some biological effects of the stannous chloride are associated with the generation of free radicals (Dantas et al., 1999). Reducing agents are necessary on the labeling process involving the $99 \mathrm{mTc}$, and stannous ions is usually used (Saha, 2004). Lin et al. (1996) have reported that Arctium lappa has free radical-scavenging activities. Probably this activity would be not too strong, due to the burdock extract was not capable to interfere on the labeling plasma and cellular proteins (Table 2 and 3).

In the clinical and laboratory investigation, the morphological analysis of RBC could aid to understand physiological disorders (Engström and Löfvenberg, 1998). Concerning to other important approach related with the morphological analysis, it has demonstrated that roast coffee beans Coffea arabica extract altered the shape of red blood cells (Oliveira et al., 2003). These results were also found with burdock extract at the highest concentrations (Table 4) with a significant $(p<0.05)$ alteration of the perimeter/area ratio of red blood cells isolated from whole blood samples incubated the burdock extract. The qualitative analysis has also showed morphologic alterations on the shape of the red blood cells from blood samples incubated with this extract (Fig. 3).

Although the exact mechanism related with the effect of the burdock extract on the labeling of $\mathrm{RBC}$ is not elucidated yet, the damages observed on the membrane of the RBC could alter the transport of ions (stannous and pertechnetate ions) through the cellular membrane and could justify the decrease of labeling of red blood cells with ${ }^{99 \mathrm{~m}} \mathrm{Tc}$.

\section{ACKNOWLEDGEMENTS}

The present work was carried out with financial support of the Coordenação de Aperfeiçoamento de Pessoal de Nível Superior (CAPES), Fundação Carlos Chagas Filho de Amparo a Pesquisa do Estado do Rio de Janeiro (FAPERJ), Conselho Nacional de Desenvolvimento Científico e Tecnológico (CNPq) and Universidade do Estado do Rio de Janeiro.

\section{RESUMO}

Arctium lappa (bardana) tem sido utilizada na medicina popular para o tratamento de processos inflamatórios. Constituintes sangüíneos marcados com tecnécio-99m $\left.{ }^{99 \mathrm{~m}} \mathrm{Tc}\right)$ são utilizados na medicina nuclear para obtenção de imagens. Neste trabalho foi avaliada a influência de um extrato de bardana na marcação de constituintes sangüíneos com ${ }^{99 \mathrm{~m}} \mathrm{Tc}$ e na morfologia de hemácias. Amostras de sangue de ratos Wistar foram incubadas com extrato de bardana e o processo de radiomarcação de constituintes sangüíneos foi realizado. Plasma e células sangüíneas, frações solúvel e insolúvel do plasma e das células sangüíneas foram separadas, a radioatividade em cada fração foi contada e as porcentagens de radioatividade (\%ATI) foram determinadas. A morfologia e a relação perímetro/área das hemácias foram avaliadas. A incubação de sangue com o extrato de bardana alterou significativamente $(\mathrm{p}<0.05)$ a \%ATI a distribuição de radioatividade nos compartimentos plasmático e celular. A relação perímetro/área de hemácias, bem como a forma das hemácias também sofreram alterações Modificações na membrana poderiam justificar a diminuição da marcação das células sangüíneas com ${ }^{99 \mathrm{~m}} \mathrm{Tc}$ obtidas neste estudo.

\section{REFERENCES}

Abreu, P. R.; Almeida, M. C.; Bernardo, R. M.; Bernardo, L. C.; Brito, L. C.; Garcia, E. A.; Fonseca, A. S. and Bernardo-Filho, M. (2006), Guava extract (Psidium guajava) alters the labelling of blood constituents with technetium 99m. J. Zhejiang. Univ. Sci., 7, 429-435.

Barcia, J. J. (2007), The Giemsa stain: its history and applications. Int. J. Surg. Pathol. 15, 292-296. 
Berezina, T. L.; Zaets, S. B. and Machiedo, G. W. (2004), Alterations of Red Blood Cell Shape in Patients with Severe Trauma. J. Trauma-Injury Infection Critical Care., 57, 82-87.

Bernardo-Filho, M.; Iacy, N. S. M. and Edson, M. B. (1983), ${ }^{99 m}$ Technetium- Labeling red blood cells "in vitro". Arq. Biol. Tecnol., 26, 455-461.

Bernardo-Filho, M.; Nogueira, J.; Sturm, J. and Boasquevisque, E. (1990), Plasma proteins labelling with 99m Technetium. Braz. Arch. Biol. Technol. 33, 811-817.

Bernardo-Filho, M.; Santos-Filho, S. D.; Moura, E. G.; Maiworm, A. I.; Orlando, M. M. C.; Penas, M. E.; Cardoso, N.; Bernardo, L. and Brito, L. C. (2005), Drug interaction with radiopharmaceuticals: a review. Braz. Arch. Biol. Technol., 48, 13-27.

Dantas, J. S. F.; Morais, O.; Mattos, C. P. J.; Bezerra, J. A. C. R.; Carvalho, F. E.; Bernardo-Filho, M. and Araújo, C. A. (1999), Stannous chloride mediates single strand breaks in plasmid DNA through reactive oxygen species formation. Toxicol. Lett., 110, 129136.

Engström, K. G. and Löfvenberg, E. (1998), Treatment of myeloproliferative disorders with hydroxyurea: effects on red blood cell geometry and deformability Blood. Am. Society J. Hematol., 91, 3986-3991.

Fernandes, J. F.; Brito, L. C; Frydman, J. N. G.; SantosFilho, S. D. and Bernardo-Filho, M. (2005), An aqueous extract of Pfaffia sp. does not alter the labeling of blood constituents with technetium-99m and the morphology of the red blood cells. Braz. J. Pharmacogn., 15, 126-132.

Fonseca, A. S.; Frydman, J. N.; Rocha, V. C. and Bernardo-Filho, M. (2007), Acetylsalicylic acid decreases the labeling of blood constituents with technetium-99M. Acta Biol Hung. 2, 187-98.

Hunt, A.; Frier, M.; Johnson, R.; Berezenko, S. and Perkins, A. C. (2006), Preparation of Tc-99mmacroaggregated albumin from recombinant human albumin for lung perfusion imaging. Euro. $J$. Pharmaceut. Biopharmaceut., 62, 26-31.

Iwakami, S.; Wu, J. B.; Ebizuka, Y. and Sankawa, U. (1992), Platelet activating gastro factor (PAF) antagonists contained in medicinal plants: lignans and sesquiterpenes. Chem. Pharm. Bull., 40, 1196-1198.

Lieber, C. S. (1994), Alcohol and the liver. Gastroenterology, 106, 1085-1105.

Lin, C. C.; Lu, J. M.; Yang, J. J.; Chuang, S. C. and Ujiie, T. (1996), Anti-inflammatory and radical scavenge effects of Arctium lappa. Am. J. Chin. Med., 24, 127-137.

Moreno, S. R .F.; Diré, G.; Freitas, R. S.; Farah, M. B.; Lima-Filho, G. L.; Rocha, E. K.; Jales, R. L. C. and Bernardo-Filho, M. (2002), Effect of Ginkgo biloba on the labeling of blood elements with technetium99m: in vitro study. Rev. Bras. Farmacogn., 12, 6263.
Moreno, S. R. F.; Freitas, R S.; Rocha, E. K.; LimaFilho, G. and Bernardo-Filho, M. (2004), Protection of plasmid DNA by Ginkgo biloba from the effects of stannous chloride and the action on the labeling of blood elements with technetium-99m. Braz. J. Med. Biol. Res., 37, 267-271.

Moreno, S. R. F.; Rocha, E. K.; Pereira, M., MandarimLacerda, C.; Freitas, R. S.; Nascimento, A. L. R.; Carvalho, J. J.; Lima-Filho, G. L.; Diré, G.; Lima, E. A. C. and Bernardo-Filho, M. (2004), Ginkgo biloba extract: experimental model to evaluate its action on the labeling of blood elements with Technetium-99m and on the morphometry of red blood cells. Pak. J. Nutr., 3, 68-71.

Morita, T.; Ebihara, K. and Kiriyama, S. (1993), Dietary fiber and fat-derivatives prevent mineral oil toxicity in rats by the same mechanism. J. Nutrition. , 123, 1575-1585.

Oliveira, J. F.; Santos-Filho, S. D.; Catanho, M. T. J.; Srivastava, S. C.; Lima-Filho, G. and Bernardo-Filho, M. (2003), Effect of extract medicinal plants on the labeling of blood elements with technetium-99m and on morphology of red blood cells (RBC): toxicological action of roast coffee beans (Coffea Arabica). Indian J. Nucl. Med., 18, 52-56.

Oliveira, J. F. F.; Brito, L. C.; Frydman, J. N. D.; Santos-Filho, S. D. and Bernardo-Filho, M. (2005), An aqueous extract of Pfaffia sp. does not alter the labeling of blood constituents with technetium-99m and the morphology of the red blood cells. Braz. J. Pharmacol., 15, 126-132.

Owunwanne, A.; Patel, M. and Sadek, S. (1995), Preparation of radiopharmaceuticals. The hand book of radiopharmaceuticals. London: Chapman and Hall Medical.

Panis, C. and Souza, M. (2005), Methods of measuring volume changes in erythrocytes under hyposmotic stress: a comparison. Analytical and Quantitative Cytology and Histology., 27, 95-100.

Pompei, L. M.; Carvalho, F. M.; Ortiz, S. C.; Motta, M. C.; Cruz, R. J. and Melo, N. R. (2005), Morphometric evaluation of effects of two sex steroids on mammary gland of female rats. Maturitas. 5, 370-379.

Prech, M.; Grajek, S.; Marszalek, A.; Lesiak, M.; Jemielity, M.; Araszkiewicz, A.; Mularek-Kubzdela, T. and Cieslinski, A. (2005), Chronic infarct-related artery occlusion is associated with a reduction in capillary density. Effects on infarct healing. Eur. J. Heart. Fai.l. 8, 373-80.

Rotblatt, M. and Ziment, I. (2002), Evidence-Based Herbal Medicine. Philadelphia. Hanley and Belfus.

Saha, G. B. (2004). Fundamentals of Nuclear Pharmacy. New York. Springer. 
Shimazawa, M.; Tomita, G.; Taniguchi, T.; Sasaoka, M.; Hara, H.; Kitazawa, Y. and Araie, M. (2006), Morphometric evaluation of changes with time in optic disc structure and thickness of retinal nerve fibre layer in chronic ocular hypertensive monkeys. Exp. Eye Res., 3, 427-440.

Song-Chow, L.; Chia-Hsien, L.; Chun-Ching, L.; YunHo, L.; Chin-Fa, C.; Cheng, C. and Li-Ya, W. (2002), Hepatoprotective effects of Arctium lappa linne on liver injuries induced by chronic ethanol consumption and potentiated by carbon tetrachloride. J. Biol. Sci., 5, 401-409.
Santos-Filho, S. D. and Bernardo-Filho, M. (2005), Efeito de um extrato de Hipericum perforatium na marcação in vitro de elementos sanguíneos com tecnécio-99m e na biodisponibilidade do radiofármaco pertecnetato de sódio em ratos Wistar. Acta Cir. Bras., 20, 121-125.

Schneider, A.; Attaran, M.; Gratz, K. F.; Bleck, J. S.; Winkler, M.; Manns, M. P. and Ott, M. (2003), Intraportal infusion of 99mtechnetium-macroaggregrated albumin particles and hepatocytes in rabbits: assessment of shunting and portal hemodyn changes. Exp. Transplant., 75, 296-302. 